\title{
LATAR HISTORIS INDIKATOR KERELAAN PEREMPUAN DALAM PERKAWINAN
}

\author{
Ramadhita \\ Fakultas Syari'ah UIN Maulana Malik Ibrahim Malang \\ gedherama@gmail.com
}

\begin{abstract}
Abstrak
Free will is one of Islamic teaching principle in both worship and muamalah activities. The basis of free will also implemented in the marriage matters as stated by Rasulullah. "Silence" is usually indicated as agreement from woman, but yet, it is often indicated partially and denying its socio-historical context. The guardian of woman often hegemonic and force the woman under his guardianship to marriage, without considering her psychological condition, attitudes, and basic rights in marriage. The use of "signal" basically must be compromised from both giver and receiver of signal dialogically. As was exampled by Rasulullah when approving the proposal from Ali bin Abi Thalib.

Suka rela merupakan salah satu prinsip ajaran Islam dalam aktivitas ibadah maupun muamalah. Asas suka rela juga diimplementasikan dalam bidang perkawinan sebagaimana ditegaskan dalam beberapa hadits Rasulullah SAW. Indikator yang digunakan yaitu iyarat "diam" dari calon mempelai perempuan. Namun, tidak jarang hadits tentang indikator ini dipahami secara parsial dan manafikan konteks sosio-historisnya. Wali sering kali melakukan hegemoni dan pemaksaan terhadap perempuan yang ada di bawah perwaliannya, tanpa memperhatikan kondisi psikologisnya, perubahan sikap, dan hak-hak dasarnya dalam perkawinan. Penggunaan sebuah isyarat pada dasarnya harus disepakati terlebih dahulu oleh pemberi isyarat dan penerima isyarat dalam proses dialogis. Sebagaimana yang dicontohkan Rasulullah SAW pada saat menerima peminangan dari Ali bin Abi Thalib.
\end{abstract}

Kata Kunci: Kerelaan, perempuan, perkawinan

Sebagai agama paripurna, Islam sejak awal berupaya menghapus penindasan, perbudakan, pemaksaan serta memberi pembelaan terhadap kaum lemah (al-mustadz'afin). Visi dan misi Islam selalu berkaitan dengan persoalan pembebasan dan kesetaraan, yang mendapat legitimasi melalui dua sumber otoritatifnya yaitu al-Quran dan al-Hadits. Secara historis, Islam memberikan perhatian lebih terhadap tiga kelompok rentan, yaitu orang miskin, budak, dan perempuan. Dalam berbagai persoalan, ajaran Islam berupaya menghapuskan perbudakan. Misalnya, dalam Q.S. al-Mujadilah [58]: 3 dinyatakan bahwa seorang suami yang men- $d z$ ihar $^{1}$ istrinya wajib memerdekakan seorang budak, sebelum kembali berhubungan dengan

\footnotetext{
${ }^{1}$ Dzihar adalah ucapan suami yang menyerupakan istri seperti ibunya. Dalam konteks Arab Pra-Islam dzihar digunakan untuk menceraikan istri. Setelah Islam datang dzihar tidak menyebabkan perceraian, tapi bagi pelakunya dikenai sanksi yaitu membebaskan seorang budak, jika tidak sanggup maka berpuasa dua bulan berturut-turut, jika tidak sanggup maka memberi makan enam puluh orang miskin. Merujuk pada pendapat Ali Sodoqin, maka al-Qur'an sedang melakukan proses taghyir (adoptive-reconstructive), yaitu menerima tradisi Arab tetapi memodifikasinya sedemikian rupa sehingga berubah karakter dasarnya. Lebih lanjut lihat Ali Sodiqin, Antropologi al-Qur'an Model Dialektika Wahyu dan Budaya (Yogyakarta: Ar Ruzz Media, 2008), h. 116-135.
} 
istrinya. Islam juga memberikan perlindungan dan mengangkat derajad wanita. Perempuan diberikan hak yang sama dengan laki-laki dalam berbagai aspek, seperti hak hidup, hak beribadah, hak menerima mahar, hak menerima nafkah dan hak saling mewarisi. ${ }^{2}$ Melalui ajaran-ajaran ini, wajar jika pengikut Islam pertama kali didominasi oleh tiga kelompok ini.

Sebagai agama pembebas, -meminjam istilah Asghar Ali Engineer- Islam juga mengajarkan tidak adanya paksaan dalam melakuan segala aktifitas. Prinsip ini tidak hanya berlaku pada konteks ibadah sebagaimana firman Allah SWT. dalam Q.S. al-Baqarah [2]: 256, tetapi juga dalam konteks muamalah. Menurut Ahmad Wardi Muslich, larangan memaksakan kehendak kepada orang lain memunculkan prinsip suka rela (antaradhin) yang menjadi penentu keabsahan semua akad muamalah. Sebagaimana firman Allah SWT dalam Q.S. al-Nisa [4]: 29. ${ }^{3}$ Dalam akad perkawinan, Rasulullah Saw bersabda:

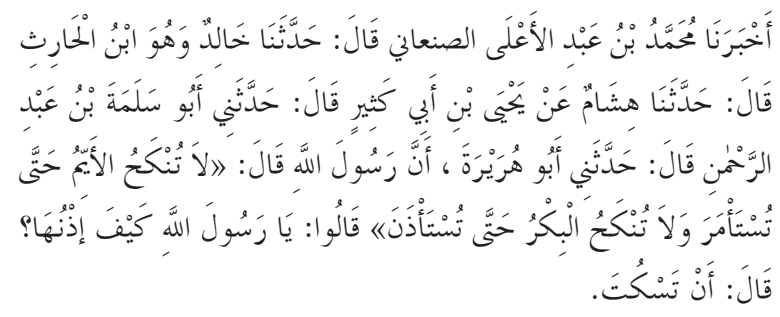

Artinya: diriwayatkan dari Abu Hurairah, sesungguhnya Rasulullah SAW bersabda: "Jangan kamu menikahkan janda hingga ia memberikan persetujuan, dan jangan kamu menikahkan gadis sampai ia memberikan izin" kemudian para sahabat bertanya "Wahai Rasulallah bagaimana ciri persetujuannya?" Rasulullah SAW menjawab: " dengan diamnya". ${ }^{4}$ (H.R. al-Nasa'i)

${ }^{2}$ Asghar Ali Engineer, Islam dan Teologi Pembebasan, Terj. Agung Prihantoro (Yogyakarta: Pustaka Pelajar, 2003), 235-25; lihat juga Amina Wadud, Qur'an Menurut Perempuan Membaca Kebali Kitab Suci dengan Semangat Keadilan, Terj. Abdullah Ali (Jakarta: Serambi, 2006), h. 107-134.

${ }^{3}$ Ahmad Wardi Muslich, Figh Muamalat (Jakarta:Amzah,2010), h. 5.

${ }^{4}$ Ahmad ibn Syu'aib al-Nasa'i, Kitab al-Sunan al-Kubra Juz V (Beirut: Muassasah al-Risalah, 2001), h.173.
Hadits di atas memberikan arahan atau rekomendasi bagi seorang wali untuk meminta persetujuan dari calon mempelai perempuan sebelum dikawinkan. Adanya unsur kerelaan calon mempelai perempuan diharapkan mampu mewujudkan fungsi-fungsi keluarga secara maksimal. Djuju Sudjana sebagaimana dikutip Mufidah Ch, yang mengatakan bahwa ada tujuh fungsi keluarga, fungsi biologis, edukatif, religius, protektif, sosialiasi, rekreatif, dan ekonomis. ${ }^{5}$ Fungsi-fungsi ini tidak pernah berjalan dengan baik jika tidak didasari asas tersebut. Berdasarkan teks atau matan hadits di atas, indikator yang menunjukkan persetujuan itu adalah diamnya seorang perempuan. Sebagian kalangan kemudian mempersoalkan hadits di atas, sebab diamnya seorang perempuan memiliki berbagai interpretasi. Selain itu, hadits di atas seolah melegitimasi adanya hegemoni laki-laki - ayah dan kakek sebagai wali- terhadap anak-anak perempuan mereka. Persoalannya kemudian apakah indikator persetujuan calon mempelai perempuan di atas diterima begitu saja (taken for granted) atau melihat konteks historis turunnya hadits (asbabul wurud). Paper ini mencoba untuk mengurai dan menyegarkan kembali pemaknaan terhadap indikator persetujuan perempuan dalam perkawinan sehingga tidak lagi muncul stigma atau peminggiran akan hadits Nabi Saw.

\section{Penelitian Kualitas Hadits Persetujuan Perempuan}

Pemahaman terhadap sebuah hadits selalu dimulai dari persoalan keabsahan atau orisinalitas transimisinya. Sebagai sumber otoritatif kedua setelah al-Qur'an, pembukuan hadits baru dilakukan pada masa Khalifah Umar bin Abdul Aziz (99-101 H) yang mengirim surat kepada Abu Bakar Muhammad ibn Hazm dan Muhammad bin Muslim bin Shihab al-Zuhri. ${ }^{6}$ Pada rentang waktu dua abad dari wafatnya Rasulullah Saw, rantai transmisi hadits (isnad) sudah sangat panjang, redaksi hadits pun yang

${ }^{5}$ Mufidah Ch., Psikologi Keluarga Berwawasan Gender (Malang:UIN Malang Press, 2008), h. 42-43

${ }^{6}$ Umi Sumbulah, Kajian Kritis Ilmu Hadits (Malang: UIN-Malang Press, 2010), h. 47. 
beragam ditambah dengan upaya pemalsuan hadits dengan berbagai macam motif perlu dilakukan kritik atau penilaian terhadap transmisi hadits.

Melalui kitab al-Mu'jam al-Mufahras li Alfadz al-Hadits al-Nabawy, ${ }^{7}$ dengan menggunakan kata kunci - تنكح نكح menunjukkan bahwa hadits meminta persetujuan wali tidak hanya di-takhrij oleh al-Nasai saja,^ melainkan juga oleh al-Bukhari, " Muslim, ' al-Tirmidzi, " dan Abu Dawud. "Banyaknya rawi yang meriwayatkan hadits menunjukkan bahwa persetujuan calon mempelai perempuan di atas bukan hadits gharib." Meskipun demikian, berdasarkan berbagai redaksi yang ditemukan,' ${ }^{\prime k}$ hadits tersebut diriwayatkan secara ma'nawi. Menurut Khusniati Rofi'ah, periwayatan bi al-ma'na yaitu periwayatan hadits yang redaksinya atau matannya tidak persis sama dengan apa

${ }^{7}$ A.J. Wensinck, Al-Mu'jam Al-Mufahras li Alfadz alHadits Al-Nabawi, Juz I (Laiden: Maktabah Barl,1936), 46

${ }^{8}$ Ahmad ibn Syu'ab al-Nasa'i, Kitab al-Sunan al-Kubra Juz V (Beirut: Muassasah al-Risalah, 2001), h. 173

${ }^{9}$ Ahmad ibn 'Aly ibn Hajar al-'Asqalany, Fath Bary bi Syarh Shahih al-Bukhary, Juz XI (Riyad: Dar Thibah, 2006), h. 456

${ }^{10}$ Muslim ibn Hajjaj, Shahih Muslim,Juz I (Riyad: Dar Thibah, 1998), h. 641

${ }^{11}$ Muhammad Ibn 'Isa al-Tirmidzi, al-Jami' al-Kabir Juz II (Beirut:Dar al-Garb al-Islamy,1998), h. 401

${ }^{12}$ Sulaiman ibn al-Asy'ats al-Sajstani, Sunan Abi Dawud Juz II (Beirut: Dar al-Fikr, 1998), h. 195

${ }^{13}$ Menurut Fatchur Rahman hadits gharib adalah hadits yang dalam sanadnya terdapat seseorang yang menyediri dalam meriwayatkan, dimana saja penyendirian dalam sanad itu terjadi. Lihat Fatchur Rahman, Ikhtisar Musthalahul Hadits (Bandung: al-Ma'arif, 1974), h. 97.

${ }^{14}$ Dalam proses penelusuran hadits tentang persetujuan calon mempelai, penulis menemukan berbagai redaksi sebagai berikut:

a.Al-Bukhari meriwayatkan hadits sebagai berikut:

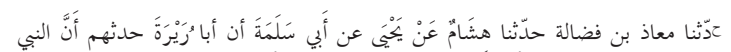

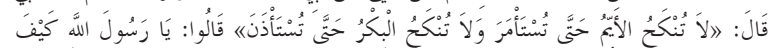

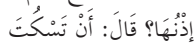

b. Muslim dalam kitab shahihnya menyebutkan:

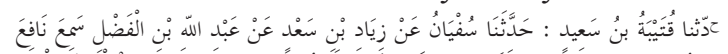

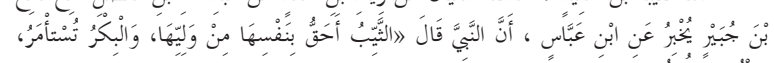

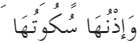

c.Al-Tirmidzi dalam kitab sunan-nya menyebutkan:

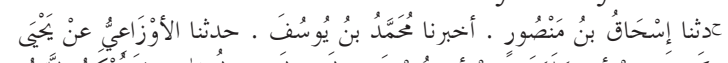

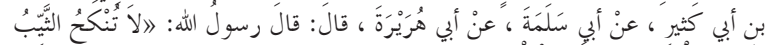

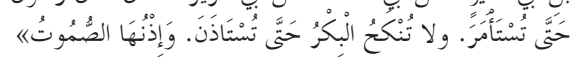

yang diucapkan nabi, namun maknanya sama dengan yang dimaksudkan oleh Nabi Saw. ${ }^{15}$

Dari segi kebersambungan sanad dan kualitas perawinya hadits tersebut tidak diragukan, terlebih hadits tersebut di-takhrij oleh alBukhari dan Muslim. Menurut al-Bukhari kebersambungan sanad dapat dibuktikan dengan cara: (1) al-liqa', yaitu adanya pertautan langsung antara satu perawi dengan perawi berikutnya, dibuktikan dengan hubungan serta interaksi langsung antara guru dengan murid; (2) al-mu'asyarah, yaitu persamaan masa hidup antara seorang guru dengan seorang murid. Sedangkan menurut Imam Muslim suatu sanad dikatakan bersambung jika antara satu perawi dengan perawi berikutnya ada kemungkinan bertemu karena hidup pada kurun waktu yang tidak jauh berbeda dan tempat tinggalnya juga berdekatan. ${ }^{16}$

Al-Bukhari dan Muslim dikenal sebagai kritikus hadits yang selektif dalam menerima sebuah periwayatan. Penilian terhadap kualitas dan kredibilitas perawi sangat dipertimbangkan. Dari sisi kualitas seorang perawi harus berisifat adil. Menurut para kritikus hadits setidaknya ada empat ciri keadilan dalam diri perawi: Pertama, Muslim adalah unsur utama dalam konsep adil. Sehingga seseorang yang akan menyampaikan hadits maka harus berstatus muslim. Non-muslim hanya boleh mendengarkan saja tidak boleh meriwayatkan; Kedua, Mukallaf adalah orang yang dianggap cakap hukum. Dalam konteks ini, anak-anak boleh mendengarkan hadits dan baru bisa meriwayatkannya pada saat baligh. Para ulama berbeda pendapat tentang batas usia anak-anak. Mayoritas menyatakan bahwa usia 5 tahun sudah diperbolehkan karena dianggap sudah mumayyiz. Sedangkan Yahya bin Ma'in mengatakan bahwa usia minimalnya adalah 15 tahun; Ketiga, Melaksanakan ketentuan agama dan tidak melakukan perbuatan dosa; Keempat, memelihara moralitas atau muru'ah. Seorang perawi tidak diperbolehkan melakukan perbuatan yang merusah moralnya, meskipun

\footnotetext{
${ }^{15}$ Khusniati Rofi'ah, Studi Ilmu Hadith (Ponorogo:STAIN Ponorogo Press, 2010), h. 17.

${ }^{16}$ Umi Sumbulah, Kajian, h. 97.
} 
hukumnya mubah. Misalnya makan sambil berdiri atau tertawa terbahak-bahak. ${ }^{17}$

Selain itu, perawi haruslah sosok yang kredibel di bidangnya, ditandai dengan adanya sifat dhabith, yaitu kuat hafalannya tentang apa yang telah didengar dan mampu menyampaikan hafalan kapan saja bila dikehendaki. Menurut al-Syarkhasi kata dhabith berarti tingkat kemampuan dan kesempurnaan intelektualitas seseorang dalam proses penerimaan hadits, mampu memahami secara mendalam makna yang dikandungnya, menjaga dan menghafal semaksimal mungkin hingga pada waktu penyebaran dan periwayatan hadits yang didengar tersebut kepada orang lain.

Pengujian sanad hadits, penulis fokuskan pada riwayat al-Nasa'i dari Abu A'la alShan'ani. Berdasarkan berbagai informasi yang penulis peroleh dari kitab tahzibul kamal fi asma' al-rizal karya al-Mazzi ditemukan data yang menunjukkan bahwa hadits tentang meminta persetujuan calon mempelai perempuan diyakini berasal dari Rasulullah Saw. karena sanadnya bersambung dan kredibilitas perawi sebagaimana tergambar dalam informasi jarh wa ta'dilnya adalah orang-orang yang adil sekaligus dhabith.

$17 \quad$ Umi Sumbulah, Kajian, h. 97.

Tabel Biografi Perawi Hadits:

\begin{tabular}{|c|c|c|c|c|c|c|}
\hline No & Nama Perawi & $\begin{array}{l}\text { TL/TWI } \\
\text { Umur }\end{array}$ & & Guru & Murid & Jarh wa Ta'dil \\
\hline 1 & Abu Hurairah ${ }^{1}$ & $\begin{array}{l}\text { Wafat: } \\
57 / 58 / 59 \mathrm{H}\end{array}$ & $\begin{array}{l}1 . \\
2 . \\
3 . \\
4 .\end{array}$ & $\begin{array}{l}\text { Nabi SAW. } \\
\text { Umar Ibn Khattab } \\
\text { Abu Bakr ash- } \\
\text { Shidiq } \\
\text { 'Aisyah }\end{array}$ & $\begin{array}{ll}\text { 1. } & \text { Ibrahim ibn } \\
\text { Isma'il } \\
\text { 2. Sa'id ibn } \\
\text { Musayyib } \\
\text { 3. } \begin{array}{l}\text { Abu Salamah } \\
\text { ibn Abd al- } \\
\text { Rahman } \\
\text { 4. } \\
\text { Muhammad } \\
\text { ibn Ziyad al- } \\
\text { Jumahy }\end{array} \\
\end{array}$ & الصحابة كلهم عدول \\
\hline 2 & $\begin{array}{l}\text { Abu Salamah } \\
\text { lbn Abd al- } \\
\text { Rahman }^{2}\end{array}$ & $\begin{array}{l}\text { Wafat: } 94 \\
\mathrm{H} / 104 \mathrm{H}\end{array}$ & $\begin{array}{l}1 . \\
2 . \\
3 . \\
4 .\end{array}$ & $\begin{array}{l}\text { Usamah Ibn Zaid } \\
\text { Anas ibn Malik } \\
\text { Jabir ibn 'Abdillah } \\
\text { al-Anshari } \\
\text { Abu Hurairah }\end{array}$ & $\begin{array}{ll}\text { 1. } & \text { Muhammad ibn } \\
\text { Ibrahim ibn al- } \\
\text { Harist al-Taimi } \\
\text { 2. } \\
\text { Muhammad } \\
\text { ibn Muslim ibn } \\
\text { Syihab az-Zuhri } \\
\text { 3. } \begin{array}{l}\text { Yahya ibn Abi } \\
\text { Katsir }\end{array} \\
\text { 4. Hisyam ibn } \\
\text { Hrwah }\end{array}$ & $\begin{array}{l}\text { Muhammad } \\
\text { ibn Sa'id } \\
\text { menyebutkannya } \\
\text { dalam thabaqat } \\
\text { kedua ahl } \\
\text { madinah, dia } \\
\text { juga menilainya: } \\
\text { Tsiqah, faqih, } \\
\text { katsir al-hadits } \\
\text { Abu Zur'ah: } \\
\text { Tsiqah Imam } \\
\end{array}$ \\
\hline 3 & $\begin{array}{l}\text { Yahya ibn Abi } \\
\text { Katsir }^{3}\end{array}$ & $\begin{array}{l}\text { Wafat: } 129 \\
\mathrm{H} / 132 \mathrm{H}\end{array}$ & $\begin{array}{l}1 . \\
2 . \\
3 .\end{array}$ & $\begin{array}{l}\text { Anas ibn Malik } \\
\text { Jabir ibn 'Abdillah } \\
\text { Abu Salamah ibn } \\
\text { Abd al-Rahman }\end{array}$ & $\begin{array}{ll}\text { 1. } & \text { Aban ibn Yazid } \\
\text { al-'Athar } \\
\text { 2. } \\
\text { Hisyam ibn } \\
\text { Hassan } \\
\text { 3. } \begin{array}{l}\text { Hisyam al- } \\
\text { Dustu'iy }\end{array}\end{array}$ & $\begin{array}{l}\text { ‘Abdullah } \\
\text { ibn Ahmad } \\
\text { ibn Hanbal } \\
\text { dari ayahnya } \\
\text { mengatakan: } \\
\text { "Yahya ibn Abi } \\
\text { Katsir tergolong } \\
\text { atsbat nas, } \\
\text { jika pendapat } \\
\text { az-Zuhri } \\
\text { bertentangan } \\
\text { maka yang kata- } \\
\text { kata Yahya ibn } \\
\text { Abi Katsir yang } \\
\text { diambil" }\end{array}$ \\
\hline
\end{tabular}




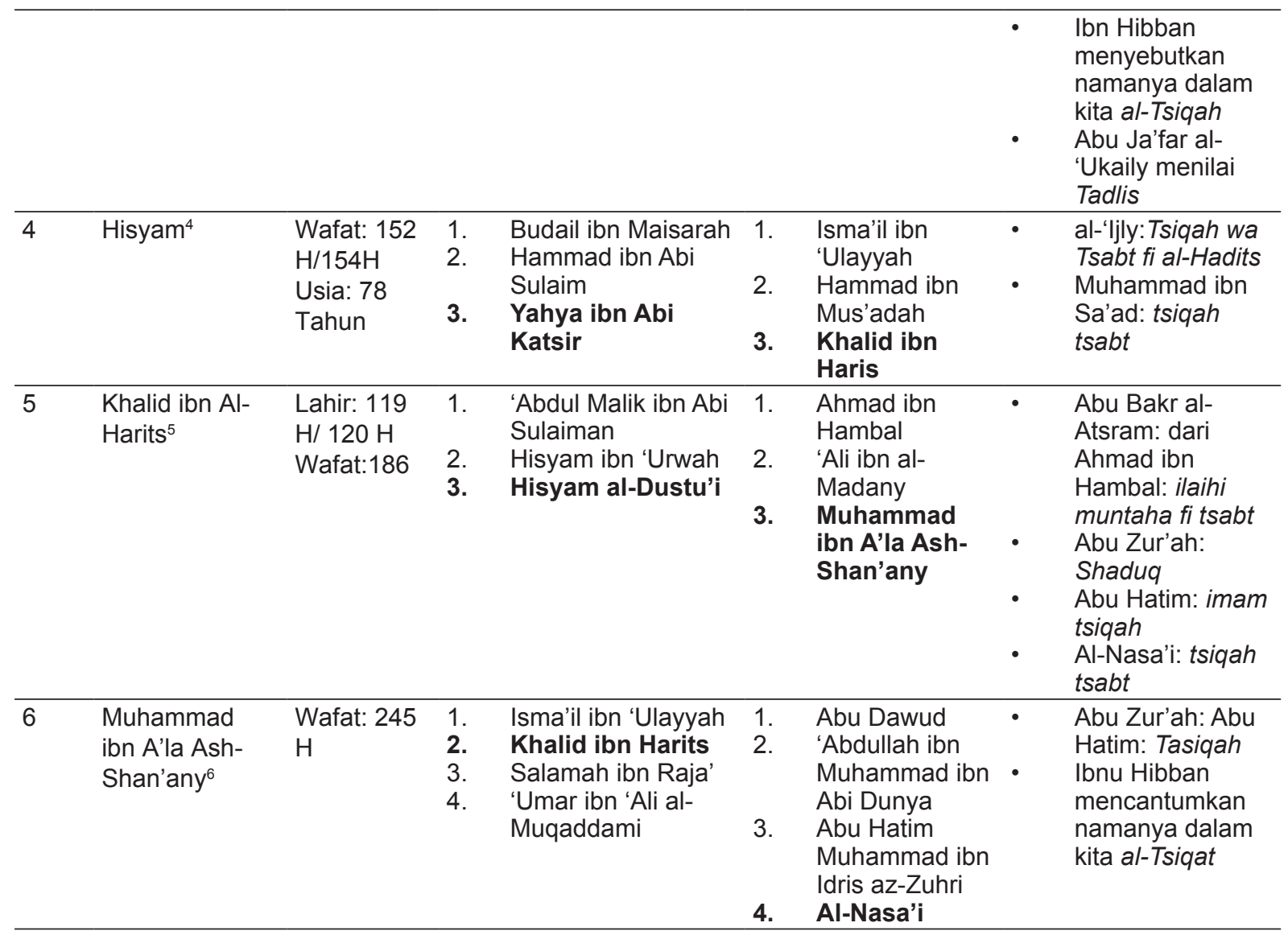

\section{Makna Diam Perempuan}

Di dalam diri manusia terdapat dimensi eksoterik yang dapat dilihat melalui panca indera dan dimensi isoterik yang bersifat abstrak, tidak terlihat, tetapi bisa dirasakan. Menurut Annemarie Schimmel, aspek-aspek ruhaniah dari kehidupan hanya dapat diungkapkan melalui aspek-aspek yang terinderai. Misalnya, angin hanya dapat dilihat melalui gerakan rumput. Debu yang terlihat dari jauh di gurun pasir, menyembunyikan seorang penunggang kuda. ${ }^{18}$ Ucapan dan perilaku lahir manusia belum tentu mencerminkan kondisi jiwanya. Dalam Q.S. At-Taubah [9]: 8 Allah SWT. berfirman:

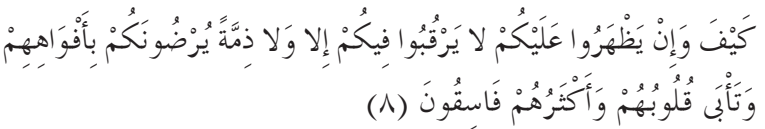

Artinya: Bagaimana bisa (ada Perjanjian dari sisi Allah dan RasulNya dengan orang-orang musyrikin),

\footnotetext{
${ }^{18}$ Annemarie Schimmel, Rahasia Wajah Suci Ilahi Memahami Islam secara Fenonenologis, Terj. Rahmani Astuti, (Bandung: Mizan, 1996), h. 22-23.
}

Padahal jika mereka memperoleh kemenangan terhadap kamu, mereka tidak memelihara hubungan kekerabatan terhadap kamu dan tidak (pula mengindahkan) perjanjian. mereka menyenangkan hatimu dengan mulutnya, sedang hatinya menolak. dan kebanyakan mereka adalah orang-orang yang Fasik (tidak menepati perjanjian).

Ayat di atas memberikan peringatan kepada umat Islam agar berhati-hati apabila melakukan perjanjian dengan orang kafir Quraisy, sebab ucapan mereka tidak sesuai dengan hati mereka. Secara eksplisit, ada inkonsistensi sikap seseorang, pernyataan di dalam hatinya tidak sesuai dengan tindakan-tindakan yang dilakukan. Padahal, ajaran Islam menghendaki adanya konsistensi dan totalitas dalam berbuat, mulai dari niat hingga aktifitas. Sikap suka rela yang merupakan sikap mental manusia, yang hanya dapat dilihat dari perilaku manusia tersebut. Atau dalam bahasa fenomenologi, esensi hanya dapat dilihat melalui manifestasi, seperti contoh terlihatnnya esensi angin melalui gerakan rumput. Meskipun demikian, 
perilaku seseorang yang nampak belum tentu merepresentasikan kondisi batinnya. Misalnya, sikap diam perempuan saat diminta persetujuannya dalam perkawinan, dengan perubahan zaman tidak lagi bisa dipahami sebagai bentuk keridhaannya.

Turunnya sebuah hadits tidak bisa dilepaskan dari aspek historisitasnya, baik yang bersifat makro maupun mikro. Asbabul wurud mikro berkaitan dengan persoalan in concreto sedangkan asbabul wurud makro berhubungan dengan kondisi geografis, sosial, budaya dan politik masyarakat Arab saat itu. Menurut Ali ibn Adam ibn Musa, ada pemisahan antara alsayyib dengan al-bikr. Diksi yang digunakan untuk keduanya pun berbeda. Kalimat alisti'mara menunjukkan adanya musyawarah, sedangkan ista'dzana digunakan digunakan untuk menggambarkan indikator yang jelas dari gadis, baik melalui ucapan dan sikap diam, karena terkadang gadis itu pemalu. ${ }^{19}$

Sikap diam yang dipahami pada masa Rasulullah, dapat dilacak dalam beberapa riwayat di bawah ini:

Diriwayatkan dari 'Atha', dia berkata, "Rasulullah saw biasa meminta izin kepada putri-putrinya yang akan dinikahkan. Rasulullah biasanya meminta putrinya untuk duduk di balik tirai dan menanyakan pendapatnya tentang lamaran seseorang atas dirinya. Jika putri beliau menggerakkan tirai maka beliau tidak akan menikahkannya. Dan jika diam saja maka Rasulullah menikahkannya."

Dari ‘Umar bahwa jika Rasulullah hendak menikahkan salah seorang perempuan, apakah itu anggota keluarganya sendiri atau kerabat keluarga terdekatnya, beliau akan menjumpai perempuan tersebut dari balik tirai sembari mengatakan " wahai putriku, sesungguhnya si fulan telah meminangmu. Jika kamu tidak menyukai, katakan tidak. Jika kamu mau maka sikap diammu merupakan bentuk persetujuanmu.

${ }^{19}$ Ali ibn Adam ibn Musa al-Atyubi al-Wallawi, Syarh Sunan al-Nasa'i Juz 29 (Mekah:Maktabah al'Arabiyah,2007), h. 219
Dari beberapa riwayat di atas, diketahui bahwa sikap diam perempuan tidak bisa digeneralisir sebagai bentuk peresetujuan. Karena diam yang dimaksud dalam hadits riwayat al-Nasa'i di atas lebih dikonotasikan sebagai diam secara fisik dan sangat simbolik, sesuai dengan kebudayaan Arab. ${ }^{20}$ Menurut Murtadha Mutahhari, ketika Rasulullah SAW menikahkan Fatimah, beliau memberikan kebebasan kepada Fatimah untuk memilih jodohnya. Menurut Murtadha, ketika Ali bin Abi Thalib menghadap Rasulullah untuk meminang Fatimah, beliau mengatakan: "Beberapa orang telah dapat kepadaku untuk melamar Fatimah, tetapi nampak rasa tidak suka di wajahnya, maka ia menolak mereka, sekarang aku akan memberi tahu dia perihal permohonanmu. Lalu Rasulullah menanyakan kepada Fatimah dan tidak ada tanda-tanda menolak, dengan sikap diam dan perasaan tidak terusik, Fatimah mengungkapkan persetujuannya." 21

Berdasarkan penjelasan Murtadha di atas, boleh jadi diamnya seseorang menandakan persetujuannya, akan tetapi perlu dicatat bahwa ada proses komunikasi antara Rasulullah Saw dengan Fatimah tentang penggunaan simbol tertentu untuk menunjukkan persetejuan. Selain itu, kondisi psikologis yang termanifestasi melalui perubahan sikap juga mendapat perhatian. Memilihkan jodoh yang terbaik untuk anak pada dasarnya diperbolehkan dalam agama, akan tetapi perlu dipertimbangkan pandangan anak, bagaimana sikap lahir dan batinnya, karena diam bukan satu-satunya indikator persetujuan. Diam hanya salah satu isyarat, yang menurut Marcel Danesi bisa berbedabeda penggunaannya dari satu daerah dengan daerah yang lain, tergantung budayanya. ${ }^{22}$

${ }^{20}$ Iklilah Muzayyahnah Dini Fajriyah, Problematika Ijbar dalam Tradisi Perjodohan di Pesantraen Nisa' Pasuruan, dalam Irwan Abdullah, dkk., Dialektika Teks Suci Agama Strukturasi Makna Agama da;am Kehidupan Masyarakat (Yogyakarta: Sekolah Pasca Sarjana UGM dan Pustaka Pelajar, 2008), h. 29

${ }^{21}$ Murtadha Muthahhari, Women adn Her Rights in Islam, terjemah Ilyas Hasan, Perempuan dan Hak-Haknya dalam Pandangan Islam (Jakarta:Lentera, 2009), h. 88

${ }^{22}$ Marcel Danesi, Messages, Signs, and Meanings: A Basic Texbook in Semiotics and Communication Theori, 
Banyak pakar semiotika dan lingistik yang menganggap bahwa isyarat merupakan bentuk komunikasi yang lebih mendasar daripada bahasa vokal. Misalnya, untuk berkomunikasi dengan orang-orang asing, secara naluriah kita memakai isyarat untuk menyampaikan sebuah pesan atau merundingkan makna. ${ }^{23}$ Apa yang dikemukakan oleh Marcel Danesi dan Desmond Morris dapat digunakan untuk memahami kata antaskut, shumutiha, atau sukutiha dalam hadits di atas. Dalam konteks budaya Arab dapat dipahami bahwa persetujuan perempuan saat itu bisa jadi melalui sikap diam, namun hal ini tidak bisa digenelalisir untuk semua wilayah. Di Indonesia misalnya, secara sosiologis budaya masyarakatnya adalah budaya terbuka, sehingga setiap pendapat dapat dikemukakan, tidak memandang laki-laki maupun perempuan. Sehingga, jika seorang perempuan diam pada saat diminta persetujuannya dalam perkawinan, harus digali lebih dalam apakah ia benar-benar rela atau justru menolaknya, karena alasan psikologis saja kemudian dia tidak mampu mengutarakan pendapatnya.

Berkaitan dengan sikap diamnya perempuan dalam penentuan jodoh, Iklilah Muzayyahnah Dini Fajriyah dalam penelitiannya yang berjudul Problematika Ijbar dalam Tradisi Perjodohan di Pesantraen Nisa' Pasuruan menyatakan bahwa pemaknaan simbol menundukkan kepala dan tidak berkata apa-apa sebagai bentuk persetujuan perempuan saat akan dijodohkan harus dilakukan telaah ulang. Karena tidak semua perempuan mampu menyatakan ketidaksetujuannya dangan kalimat yang tegas dan jelas. Cara perempuan mengungkapkan isi hatinya tidak selalu dengan sikap yang tegas, melainkan terkadang dengan tangisan, baik menunjukkan kesedihan maupun bahagia. ${ }^{24}$

Lebih lanjut Iklilah menyatakan bahwa tangisan perempuan sebagai bentuk penolakan

terjemah Evi Setyarini dan Lusi Lian Piantari, Pesan, Tanda, dan Makna: Buku Teks Dasar Mengenai Semiotika dan Teori Komunikasi (Yogyakarta:Jalasutra,2010), h. 79

${ }^{23}$ Marcel Danesi, Messages..., h. 80 h. 25

${ }^{24}$ Iklilah Muzayyahnah Dini Fajriyah, Problematika..., dalam perjodohan dapat dimaknai sebagai kegagalan perempuan untuk melakukan feeling negotiation yang sedang ia hadapi. Dengan menangis setidaknya ia menumpahkan ketidakmampuan dirinya menghadapi kuasa wali. Jika memang fungsi wali sebagai pelindung dan penyelamat perempuan, seyogyanya wali mempertimbangkan kondisi kejiwaan perempuan dan perjodohan yang dilakukan bersifat tawaran, bukan paksaan. Sehingga hadits yang menyatakan perempuan perawan dimintai pendapatnya dapat benar-benar terlihat keperpihakannya kepada hak perempuan sebagai manusia. Dengan demikian, perlu adanya upaya klarifikasi sebagai ikhtiar mendapatkan gambaran yang sebenarnya dari simbol-simbol fisik yang diperlihatkan perempuan. ${ }^{25}$

Ada berbagai cara yang dapat digunakan untuk memunculkan sikap suka rela, misalnya dengan jalan musyawarah mufakat. Melalui komunikasi yang intensif dan dibangun dalam suasana kekeluargaan para pihak yang terlibat mampu mengetahui dan menganalisis position, interest dan need masing-masing. Menurut Ahwan Fanani, posisi adalah tuntutan spesifik dari masing-masing pihak dan bersifat hitamputih, benar-salah. Sementara itu, interest adalah apa yang sebenarnya diinginkan oleh masing-masing pihak. Interest adalah tujuan abstrak yang ingin dicapai masing-masing pihak. Interest bisa mewakili kebutuhan dasar manusia. Sehingga, untuk mewujudkan prinsip kerelaan dalam perkawinan komunikasi yang efektif antara orang tua dan anak bukan sekedar bertahan pada posisi atau simbol melainkan bergerak pada aspek interest dan kebutuhan si anak akan perkawinannya. Orang tua memberikan arahan dan rekomendasi terkait dengan persoalan-persoalan yang belum pernah dilalui oleh si anak. Sementara itu, si anak juga semaksimal mungkin mengkompromikan apa yang menjadi interest dan kebutuhan dari orang tua.

\footnotetext{
${ }^{25}$ Iklilah Muzayyahnah Dini Fajriyah, Problematika, 27
} 


\section{Kesimpulan}

Berdasarkan berbagai uraian di atas dapat disimpulkan bahwa hadits tentang meminta persetujuan calon mempelai perempuan diyakini berasal dari Rasulullah Saw karena kebersambungan sanad (chain of transmition) dapat dipertanggung jawabkan. Selain itu para perawinya diakui oleh para kritikus hadits sebagai perawi yang dhabith. Para ulama ahli hadits

\section{DAFTAR PUSTAKA}

A.J. Wensinck. Al-Mu'jam Al-Mufahras li Alfadz al-Hadits Al-Nabawi, Juz I Laiden: Maktabah Barl, 1936

al-Mazzi, Jamal al-Din Abi al-Hajjaj Yusuf. Tahdzib al-Kamal fi Asma' al-Rijal.Beirut: Muassasah al-Risalah, 2002.

al-Nasa'i, Ahmad ibn Syu'aib. Kitab al-Sunan al-Kubra.Beirut: Muassasah al-Risalah, 2001.

al-Sajstani, Sulaiman ibn al-Asy'ats. Sunan Abi Dawud Juz II.Beirut: Dar al-Fikr, 1998.

al-Tirmidzi, Muhammad Ibn 'Isa. al-Jami' alKabir Juz II.Beirut:Dar al-Garb al-Islamy, 1998..

al-Wallawi, Ali ibn Adam ibn Musa alAtyubi. Syarh Sunan al-Nasa'i Juz 29. Mekah:Maktabah al-'Arabiyah, 2007.

Danesi,Marcel. Messages, Signs, and Meanings: A Basic Texbook in Semiotics and Communication Theori, terjemah Evi Setyarini dan Lusi Lian Piantari. Pesan, Tanda, dan Makna: Buku Teks Dasar Mengenai Semiotika dan Teori Komunikasi.Yogyakarta: Jalasutra, 2010.

Engineer, Asghar Ali. Islam dan Teologi Pembebasan, Terj. Agung Prihantoro. Yogyakarta: Pustaka Pelajar, 2003.

Fajriyah,Iklilah Muzayyahnah Dini. Problematika Ijbar dalam Tradisi Perjodohan di Pesantraen Nisa' Pasuruan, dalam Irwan Abdullah, dkk. Dialektika Teks Suci Agama Strukturasi Makna Agama daLam Kehidupan Masyarakat. Yogyakarta: Sekolah Pasca Sarjana UGM dan Pustaka Pelajar, 2008. sepakat bahwa diam adalah isyarat persetujuan seorang perempuan. Meskipun demikian, ditemukan catatan sejarah yang menunjukkan bahwa ada proses komunikasi antara Rasulullah Saw dan Fatimah yang bertujuan menyepakati simbol atau isyarat yang digunakan untuk menunjukkan persetujuan. Oleh karena itu, tidak tepat jika hadits tersebut hanya dimaknai secara leterlijk atau tekstual dan menafikan dimensi psikologis dari perempuan.

Mufidah Ch. Psikologi Keluarga Berwawasan Gender. Malang:UIN Malang Press, 2008.

Muslich, Ahmad Wardi. Figh Muamalat. Jakarta: Amzah, 2010.

Muslim ibn Hajjaj. Shahih Muslim.Riyad: Dar Thibah, 1998.

Muthahhari, Murtadha. Women adn Her Rights in Islam, terjemah Ilyas Hasan, Perempuan dan Hak-Haknya dalam Pandangan Islam. Jakarta:Lentera, 2009

Rahman, Fatchur. Ikhtisar Musthalahul Hadits. Bandung: al-Ma'arif, 1974.

Rofi'ah, Khusniati. Studi Ilmu Hadith. Ponorogo:STAIN Ponorogo Press, 2010.

Schimmel, Annemarie. Decipering the Signs of God: A Phenomenological Approach to Islam, terjemah oleh Rahmani Astuti, Rahasia Wajah Suci Ilahi Memahami Islam secara Fenonenologis.Bandung: Mizan, 1996

Shihab, M. Quraish. Tafsir al-Misbah Pesan Kesan dan Keserasian al-Quran Vol. I. Ciputat: Lentera Hati, 2000.

Sodiqin, Ali. Antropologi al-Qur'an Model Dialektika Wahyu dan Budaya. Yogyakarta: Ar Ruzz Media, 2008.

Sumbulah, Umi. Kajian Kritis Ilmu Hadits. Malang: UIN-Malang Press, 2010.

Wadud, Amina. Qur'an Menurut Perempuan Membaca Kebali Kitab Suci dengan Semangat Keadilan. Terj. Abdullah Ali. Jakarta: Serambi, 2006. 